BULLETIN Bulletin hispanique

HispaniquE Université Michel de Montaigne Bordeaux

109-2 | 2007

La formation du Parnasse espagnol $\mathrm{XV}^{\mathrm{e}}-\mathrm{XVIII}{ }^{\mathrm{e}}$ siècle

\title{
La generación de 1780 y sus parnasos
}

\section{François Lopez}

\section{(2) OpenEdition \\ Journals}

Edición electrónica

URL: http://journals.openedition.org/bulletinhispanique/359

DOI: 10.4000/bulletinhispanique.359

ISSN: 1775-3821

Editor

Presses universitaires de Bordeaux

Edición impresa

Fecha de publicación: 1 diciembre 2007

Paginación: 709-747

ISBN: 978-2-85276-096-7

ISSN: 0007-4640

Referencia electrónica

François Lopez, « La generación de 1780 y sus parnasos », Bulletin hispanique [En línea], 109-2 | 2007,

Publicado el 01 diciembre 2011, consultado el 02 mayo 2019. URL : http://journals.openedition.org/

bulletinhispanique/359 ; DOI : 10.4000/bulletinhispanique.359 


\title{
La generación de 1780 y sus parnasos
}

\author{
FranÇOIS LOPEZ \\ Université Michel de Montaigne - Bordeaux 3
}

Le concept historique du Siècle d'Or de l'Espagne a, dès son apparition, favorisé l'essor de l'histoire littéraire, des rééditions d'auteurs classiques et des anthologies poétiques consacrées aux XVI et XVII siècles. On présente ici deux de ces ouvrages, le Parnaso español de Sedano (1768-1778), et la Colección de poetas castellanos [...] d'Estala (1786-1798).

El concepto histórico de Siglo de Oro de España ha favorecido, desde su aparición, el desarrollo de la historia literaria, de las reediciones de autores clásicos, y de las antologias poéticas consagradas a los siglos XVI et XVII. Presentamos aqui dos obras de esta categoría : el Parnaso español de Sedano (1768-1778), y la Colección de poetas castellanos [...] de Estala (1786-1798).

The historical concept of "Golden Century of Spain " favoured, from its appearance, the development of literary history, as well as re-issues of classical authors and poetical anthologies dedicated to the XVIth and XVIIth centuries. This is a presentation of two of these works: the Parnaso espanol by Sedano (1768-1778) and the Coleccion de poetas castellanos (...) by Estala (1786-1798).

Mots-clés : Anthologies - Néo-classicisme - Poésie - Siècle d'or.

BHi, Tome 109, n 2 - décembre 2007 - p. 709 à 747. 
T A GEneración de 1780 es para nosotros la de los hombres de letras Lue, nacidos en los años 50 de la centuria, empezaron a publicar o escribir hacia 1780. Nos referimos a Iriarte, Meléndez Valdés, Arroyal, Forner, Estala, Moratín y a muchos más, de menor renombre. Pero como el llamado método de las generaciones siempre manifiesta ciertas fallas que han sido causa de su paulatino abandono, sobre todo por desatender ciertos vínculos intergeneracionales, ańadiremos que en la década anterior, la de los escritores nacidos en los años 40 o muy poco antes, habían visto la luz Moratín padre, Andrés, Cadalso, Capmany, Jovellanos, Vaca de Guzmán, Samaniego, Montengón, Arteaga, etc., algunos de los cuales, a veces, desempeńaron para con los primeros un papel de maestros e iniciadores.

Esos fueron, en conjunto, los autores que más destacaron durante el reinado de Carlos III en el campo de las letras, consagrándose a la poesía o a una historia literaria reciente pero ya lozana. Trascendente es el hecho de que a un resurgir de la poesía hayan correspondido los inicios de una crítica literaria sub specie historiae.

Es obvio, por otra parte, que el número de los talentos que se dedican a la literatura, ejerciendo para mantenerse algún oficio o cargo en la magistratura, la administración o la enseńanza, ha venido en notable aumento, lo cual contrasta con la escasez de autores de la época anterior. Cosa aún más notable: se acentúa poco después dicho incremento, ya que no tarda ni quince años la generación siguiente en sumarse a la anterior. Entre 1764 y 1775 nacen en efecto Cienfuegos, Mármol, Matute, Mor de Fuentes, Marchena, Arriaza, Roldán, Reinoso, Quintana, Blanco White, Lista y otros escritores que figuran todavía hoy en antologías y manuales de literatura española. Todos estos escritores, sin excepción, han sido poetas, por lo menos en cierto momento, dedicándose además a la crítica y también, no pocas veces, al teatro y al periodismo, labores que solían entonces ser hermanadas.

Comparten los poetas de ambas generaciones ciertas tendencias estéticas, porque son éstas generales y extensivas a una larga época de la historia cultural de Espańa, casi tan duradera como la del Barroco, y que iría, según ciertos estudiosos, de Luzán a Lista. Lo que mejor los une es su explicable predilección por un lenguaje llano, sencillo, claro y sin sorpresa, al que sólo pretenden conferir cierta elevación obligadas referencias a la mitología y a lo pastoril, reconocibles recursos a la retórica y una adjetivación deliberadamente convencional, mecánico traslado muchas veces de la latina. Dicho sea de paso, no les faltaron predecesores durante el Barroco, motivo por el cual la crítica moderna, reaccionando contra la tradicional, con exceso ideológica, se ha aplicado en señalar entre aquellas dos edades de la poesía 
ciertos elementos de continuidad no menos patentes que los que manifiestan una abierta ruptura ${ }^{1}$.

Comparada con la variedad del siglo anterior, es obvio que la vena poética de las Luces, también diversa a pesar de sus convenciones, pretendió afirmarse ante todo contra el Góngora de los grandes poemas y sus imitadores, designio que se explicita por lo demás en numerosos textos críticos, habiéndose producido mientras tanto en el lenguaje-digamos de fines del siglo XVII a la segunda mitad del XVIII- una drástica deflación a la par que una expiación, una penitencia colectivas debidas a que desde la centuria anterior, cuando menos, estaba la cultura española en el banquillo y constantemente reducida a la defensiva.

$\mathrm{Ni}$ que decir tiene que un sentimiento nacional exacerbado orientó generalmente las acciones y los discursos de esos individuos que vivieron sin saberlo la irrepetible plenitud de las Luces, tan ańorada ulteriormente. Nos referimos a su patriótico anhelo de explorar cada vez mejor la historia nacional, y esencialmente de vindicar la cultura de los espańoles. Una de las peculiaridades de la Ilustración fue indudablemente la voluntad de rescatar lo que había constituido siglos antes la suma de todo saber: el humanismo, es decir, en primer lugar las buenas letras, y luego, habiéndose ya cumplido suficientemente esta absoluta prioridad, las bellas letras, la poesía, toda la literatura profana.

\section{REEDICIONES Y RESCATES}

Esto que acabamos de decir explica que en su segunda mitad el siglo XVIII sea por excelencia un tiempo de reediciones, dilatado campo de estudio que, según la perspectiva adoptada, justificará métodos diversos y que desde la nuestra no podemos dejar de reexaminar ${ }^{2}$.

Nótese primero la muy distinta significación histórica que se da entre la reimpresión destinada a prolongar el éxito comercial de un libro todavía reciente y la que supone la voluntad deliberada de operar el salvamento o

1. Abrió el camino Joaquín Arce en su libro La poesía del siglo ilustrado, Madrid, Alhambra, 1981.

2. Aunque en una perspectiva muy distinta de la nuestra, es de gran interés la obra de Antonio Juárez Medina, Las reediciones de obras de erudición de los siglos XVI y XVII durante el siglo XVIII español. Véase también $\mathrm{M}^{\mathrm{a}}$. Taresa Bautista Malillos, Poesía de los siglos XVI y XVII impresas en el siglo XVIII, Madrid, C.S.I.C., Cuadernos bibliográficos, 48, 1988, Verlag Peter Lang, Frankfurt am Main, 1988. 
rescate de una obra más o menos antigua, valiosa, patrimonial y a veces clásica a pesar de ser poco conocida.

Dicho deseo de investigar, elegir y dar a luz no es un fenómeno ahistórico. No pensamos, en efecto, que pueda percibirse durante el largo reinado de Felipe $\mathrm{V}$. Hemos procurado en otro estudio señalar los motivos del desvío y el abandono que conocieron entonces las letras hispanas. Mucho tardó la nueva dinastía en aceptar y hacer suyo el legado cultural de los Austrias, en lo que había tenido aquél de glorioso o de estimable. No había otro modo de asegurar la continuidad monárquica ${ }^{3}$.

En cambio, el deseo afirmado por la Corona bajo el reinado de Fernando VI (de hecho, la política definida por el marqués de la Ensenada durante su ministerio, de 1747 a 1754), deseo de dar un fuerte impulso a todo "lo nacional» y modernizar a España fomentando las artes y las letras ${ }^{4}$, empezó casi de inmediato a dar frutos, tanto más cuanto que los proyectos, en gran parte frustrados, de Mayans, que se habían anticipado a cualquier reforma cultural desde la década de 1720-1730, ya constituían un conjunto impresionante en el campo de la erudición, la historia crítica y el humanismo.

Sigamos recordando fechas, ya que nos importa tomar apoyo en una cronología y una época que tuvieron un sentido histórico propio.

En 1753 Luis José Velázquez de Velasco, marqués de Valdeflores, dedica a Ensenada precisamente, sus Poesías que publicó D. Francisco de Quevedo Villegas con el nombre de Bachiller Francisco de la Torre, y al año siguiente, que ve la desgracia del marqués, publica el mismo autor sus Orígenes de la poesía castellana. Aunque la tesis defendida en la primera obra es desafortunada y habría no poco que enmendar en la segunda, la erudición con el tiempo ha destacado el interés de este libro por lo que concierne a la periodización de la poesía hispana y una de las primeras apariciones del concepto de «Siglo de Oro" ${ }^{5}$. Al mismo tiempo exactamente, y nos parece que el dato sólo ha sido recogido por Fernando Lázaro, decide la Academia española fundar dos premios, de elocuencia y de poesía. Dicha providencia, que fue un primer

3. «Un panorama de la vida intelectual bajo el reinado de Felipe V», Felipe Vy su tiempo, Congreso Internacional, Eliseo Serrano (Ed.), Zaragoza, Institución «Fernando el Católico», 2004, p. 513-524.

4. Debería hacerse un estudio sobre el mecenazgo ejercido por el marqués de la Ensenada. Sobre el papel que desempeñó en el nacimiento del cervantismo en fecha muy temprana, véase Antonio Mestre, Edición, prólogo y notas de la Vida de de Miguel de Cervantes Saavedra, Madrid, Espasa-Calpe, Clásicos Castellanos 172, 1972, p. LXXXII.

5. Un reciente estado de la cuestión en Pedro Álvarez de Miranda, «De nuevo sobre Siglo de Oro: reconsideración y balance», Fénix de España, Modernidad y cultura propia en la España del siglo XVIII (1737-1766), Pablo Fernández Albaladejo (ed.), Universidad de Madrid -Universitat d'Alacant- Casa de Velázquez, Madrid, 2006, p. 119-130. 
paso hacia una dirección de las artes y letras, figuraba ya en sus estatutos fundacionales pero lo más significativo es que no surtiría efecto hasta $1777^{6}$. Más pudo la evolución sociocultural que lo institucional.

Unos cuantos hitos todavía, contemporáneos de lo que pudieron descubrir en su juventud salmantina o madrileña nuestros autores del 1780. Las reediciones más trascendentes para la historia cultural española empiezan en la segunda mitad del siglo. Se trata de las Obras propias $i$ traducciones de... Fray Luis de León en la edición mayansiana de 1761, que tendrá varias reimpresiones en la centuria. Poco después, en 1765, volverán a ver la luz, editadas por Nicolás de Azara, las Obras de Garcilaso de la Vega, ilustradas con Notas, y aparecen los dos tomos de las Eróticas y traducción de Boecio de don Estevan Manuel de Villegas que serán obra predilecta de nuestros aprendices de poetas, casi coetánea de la monumental Coleccion de las obras sueltas, assi en prosa como en verso de... Lope de Vega, (XXI vols., impresos de 1776 a 1779). Luego vendrán las ediciones bilingües debidas a Juan Bautista Conti, la de la égloga primera de Garcilaso (1771) y la tan notable Colección de Poesías castellanas (1782-90), que no es otra cosa que la primera antología bilingüe que vio la luz en España.

Son constantes, además, en los epistolarios eruditos de esos años, las referencias a dichas reediciones y a otros trabajos «filológicos». De sumo interés, al respecto, son las cartas dirigidas a Gregorio Mayans por quien pretende ser su discípulo, Francisco Cerdá, donde menudean las noticias sobre aquellos rescates editoriales que aquí nos interesan. Valga un solo ejemplo tomado de una sola epístola:

Sancha imprimirá el Jáuregui, las Poesias varias se hallarán aquí. Puede Vm. enviar la Comedia contra Quevedo i la Censura del Polifemo de Góngora ${ }^{7}$.

6. Juan Pablo Forner, Cotejo de las églogas que ha premiado la Real Academia de la Lengua, Edición, prólogo y notas de Fernando Lázaro, Salamanca, CSIC, 1951, p. XII-XIII.

7. He aquí, además, para dar una idea de lo que fue el epistolario entre los dos eruditos, una de las directivas que contiene en relación con nuestro tema:

Si se resuelve que no es ocasión de juntar la Defensa de Góngora contra una carta de Cascales, se puede reservar para la colección de las obras de Jáuregui porque además de la comedia que imprimió Jáuregui contra Quevedo tengo una censura de Jáuregui contra Góngora inédita, a la qual podrían juntarse la Censura de Pedro de Valencia contra Góngora, i las defensas de Góngora contra Cascales i Faria.

Y así en muchas cartas en que apenas se trata de otros asuntos. G. Mayans y Siscar, Epistolario, XVII, Cartas literarias, Estudio preliminar, transcripción y notas por Amparo Alemany Peiró, Publicaciones del Ayuntamiento de Oliva/29, Valencia, 2000, p. 219. 
Tanta es la labor emprendida que no bastan para cumplirla los impresores de la Corte. Luego vendrán las ya mencionadas traducciones de Juan Bautista Conti y todas las reimpresiones que aún están esperando su turno.

Todo esto es de sobra conocido, tanto de los dieciochistas como de los especialistas del Siglo de Oro. Pero tal vez no lo fuera tanto un examen de aquel mismo sector editorial de las reediciones si se llevara a cabo no ya en la segunda mitad de la centuria, sino en la primera, que ha permanecido las más veces en cierta penumbra. Poco citados son hoy Bances Candamo (como lírico), León Marchante, Roca y Serna, Solís y Ribadeneyra, Silveyra y otros poetas, publicados en el siglo XVII, reeditados en el XVIII y olvidados después. Aquí también se da una máxima oposición entre el primer siglo XVIII y el segundo.

Indudablemente, a mediados de la centuria, interesa cada día más la poesía de aquel período ya designado por los españoles medianamente instruidos con la maleable denominación de Siglo de Oro. Apuntamos en otra ocasión cómo y por qué pudo variar notablemente la duración que pretendía abarcar dicho concepto, según se tratara del poderío político y militar de la monarquía española o de lo que hoy llamamos su literatura ${ }^{8}$. Quedó claro finalmente para los entendidos que si las buenas letras no habían sobrevivido a la política de Felipe II, habían seguido siendo victoriosas las armas españolas hasta 1623 y brillantes las letras hasta el reinado de Felipe IV, cuando menos. La poesía y las artes eran lo que inevitablemente obligaba a conferir al concepto que empezaba a gobernar la historia de toda la cultura hispana una máxima plasticidad. La poesía sobre todo.

\section{FORMACIÓN DE UN PARNASO}

En estas circunstancias nació, cosa que no hubiera sido posible mucho tiempo antes, la idea de proponer al público interesado la más rica colección poética que de los dorados siglos era posible rescatar en libros antiguos y códices de bibliotecas públicas o privadas. Como bien se sabe, el librero Antonio de Sancha, el maestro impresor Ibarra, un oscuro hombre de letras que sólo había publicado un sainete: Juan José López de Sedano y, durante pocos años, el aguerrido y probo erudito Francisco Cerdá fueron los que

8. Una tentativa para encuadrar históricamente el concepto de «Siglo de Oro» en François Lopez «La Ilustración: emergencia de «Siglo de oro»; gestación de «humanismo» y "Renacimiento», "Mélanges de la Casa de Vélazquez», Tome XXXI-2, Madrid, 1995, p. 147158. 
acometieron la empresa, sin tenerla por lo visto muy meditada ${ }^{9}$.Todo en ella revela en efecto la improvisación y los titubeos, evidenciando radicales cambios de rumbo, impuestos por muy diversos e imprevistos impedimentos. Todo eso ya en los dos primeros volúmenes de la colección y puede decirse que incluso antes de iniciarse la impresión.

Efectivamente el plan de publicación que pensó al principio seguir Sedano (¿aprobado por sus socios?) consistió sencillamente en reunir numerosos textos poéticos para hacerlos imprimir y despachar «en cuadernos sueltos, para hacer más benigno e insensible su coste al Público» ${ }^{10}$. Esta modalidad de producción y venta presentaba, hay que decirlo, apreciables ventajas para los colectores, los cuales desearían tantear el terreno antes de lanzarse a una empresa insegura. De hecho, como bien lo muestran las fechas de publicación de los sucesivos volúmenes, lo que se le propuso al impresor fue una idea, un proyecto que sólo tenía en su abono, lo vemos ahora, la labor y la experiencia de Cerdá.

Como estrategia comercial no hubiera sido la elegida una absoluta novedad, ya que el Caxón de sastre de Francisco Mariano Nipho, que se considera como una antología de la literatura espańola (con arreglo a la sucinta y tal vez insuficiente definición que de "antología» y «florilegio» nos da el D. RAE). había aparecido unos años antes, en 1760, como publicación periódica. Se editaban por suscripción dos pliegos semanales, fórmula editorial que había de retomarse en adelante a menudo. Numerosas y a veces singularmente apreciables fueron las piezas así publicadas ${ }^{\mathbf{1 1}}$.

Ahora bien, nos parece que una antología no es tan sólo una «Colección de trozos selectos de materia literaria», como reza la Academia, sino, además, una obra en que ha de explicitarse el deseo de mostrar, demostrar o ilustrar una proposición, De modo que en su definición no menos importan los criterios de selección que los textos elegidos. El propósito de la obra está muy claramente expresado en el Parnaso español y no se refiere a otra cosa que a la poesía, mientras que en el Caxón de sastre lo que se pretendía era tratar de muy variados temas sociales, morales, políticos, etc. utilizándose

9. No ha sido superada la riqueza documental y anecdótica del clásido estudio de Emilio Cotarelo y Mori, Iriarte y su época, Madrid, «Sucesores de Rivadeneyra», 1897. Sobre las polémicas en torno a Sedano, Iriarte y la edición de Villegas, véase todo el capítulo VII.

10. Parnaso español. Colección de poesías escogidas de los más célebres poetas castellanos, Madrid, Ibarra-Sancha, 1768-1778, 9 vols. (tomo 1, p. VII).

11. Ha tratado de esta publicación Luis Miguel Enciso Recio, Nipho y el periodismo español, Valladolid, Universidad de Valladolid, 1956, p. 197-217 Da además el autor en un utilísimo apéndice (p. 377-384) las referencias de todos los trozos incluidos por Nipho en su selección. 
la poesía más que la prosa, recogida aquella con una finalidad moral que nada tiene que ver con el quehacer poético. En suma, le obra de Nipho, en nuestra opinión, no fue una antología en la intención de su colector pero sí, probablemente, para muchos lectores de aquella época o de la nuestra. Volviendo ahora al proyecto de Sedano y Cerdá, creemos que si no se malogró ni malgastó, acabando por promover una prestigiosa colección, fue porque la coyuntura, para la imprenta y la librería españolas en particular, era ya cada día más favorable, y también porque supo ver Antonio Sancha qué oportunidad podían representar para él las reediciones de clásicos españoles, segmento no muy ocupado por Ibarra y otros impresores de la corte.

Se estaban desarrollando las artes del libro y, tras las reediciones rentables o bien financiadas desde un principio que se mencionaron anteriormente, se mostraron más emprendedores los reyes de la imprenta y la librería madrileńas, descartando la fórmula de los cuadernos sueltos y optando por asumir los gastos y riesgos de una bella edición en $8^{\circ}$, con grabados de Carmona, Maella y Fabregat. Es obvio que cuando empezó a imprimirse la colección no estaban recogidos los textos que iban a componerla, ya que duró unos once años (de 1768 a 1778) su impresión, la cual tuvo que interrumpirse en su tomo IX, sin acabar de cumplir con su cometido. Tal vez se debiera también esta larga demora al deseo de rentabilizar cada tomo antes de iniciar la elaboración del siguiente.

\section{UNA EMPRESA EDITORIAL}

Ya recordamos en el anterior apartado la relevancia que suele tener en cualquier colección de piezas o trozos selectos la copresencia de dichos componentes y de un discurso informativo. Los textos que desempeñan esta función en el Parnaso español son numerosos y variados: un prólogo que encabeza toda la obra y en cada uno de sus nueve volúmenes otro prólogo. Parecen ser todos de la misma mano, y a decir verdad no es muy arriesgada esta afirmación ya que es inconfundible el estilo de Sedano. No acabamos de entender cómo pudo decir Francisco Cerdá que había sido uno de los dos colectores de la obra. Creemos que en realidad se limitó el erudito valenciano a buscar y entregar no pocas piezas sin que corrieran de su mano la selección definitiva ni la ordenación de los poemas ${ }^{12}$.

12. He aquí la prueba, tal vez única, de que participó Cerdá en la empresa del Parnaso. En carta no fechada pero de 1768, escribía el erudito a Fernando de Velasco, Presidente de la Chancillería de Granada:

Mi dueño y favorecedor: Días hace que busco y no hallo ocasión de 
Teniendo en cuenta la larga gestación de la obra, nos parece insuficientemente documentada su historia interna. Afortunadamente debemos a Antonio Rodríguez-Moñino unas exactas descripciones de los volúmenes del Parnaso que a veces, como se verá en seguida, dicen mucho más de lo que expresan. Consta, por ejemplo, que después del reparto concertado de los ejemplares impresos por Ibarra y distribuidos por Sancha (tomos I a V), fue éste último quien, teniendo ya taller propio, diera a luz los volúmenes siguientes. (tomos VI a IX). Pero he aquí que el mismo Sancha, en 1773 , da a luz un tomo $\mathrm{V}$ «sin más variantes que el pie de imprenta, de la edición hecha por Ibarra en 1773». Y añade el bibliógrafo: "Creemos que hay error en la fecha y que debe ser $1773 \ldots »$.

Lo mismo sucede aquel año con el tomo III y parece que también en 1776 con el IV. Llama la atención la fórmula empleada por don Antonio: «Reimpresión a plana y renglón, sin más variante que la portada con nuevo pie de imprenta y año; de la edición de 1773». Estas perspicaces observaciones se publicaron en 1971. Un poco posteriores son los métodos y el léxico propuestos por Jaime Moll para el estudio del libro español antiguo,

remitir a V. S. el tomo I del Parnaso Español, de que otro amigo y yo somos los Colectores. Obra emprendida por descansar de fatigas más pesadas, $\mathrm{y}$ parece que ha sido muy bien recibida hasta de S. M., que nos enbió las gracias.

Más lejos añadía que estaba en prensa el tomo II y que «ascendería la obra a doce tomos». El 2 de marzo 1770 volvía a hablar de la obra, o más bien de su éxito en términos entusiastas:

Nuestra obra del Parnaso ha tomado mucho vuelo, nos empeńa de cada día más el favor con que ha sido recibido (el Parnaso) dentro y fuera de Espańa. Volter dicen que la ha visto, y dicho que si se prosigue, será la mejor que tenga ninguna nación en este género. ¿¿Qué será cuando vea en el tomo II el razonamiento de Colocolo por el célebre Ercilla que él tanto pondera?

El tomo II está concluido; sólo faltan las vidas de los poetas que van en él, y el Indice de piezas. El III está empezado, y concluido el II, empezará el IV; en este II van los retratos de Ercilla y Garcilaso. Están ya sacados los de Bartholomé Leonardo de Argensola, Quevedo y Lope de Vega. En cada tomo irán dos. Vea V. I. si sabe de algunos originales de los célebres poetas.

V. Antonio Rodríguez-Moñino, La Imprenta de Don Antonio Sancha (1771-1790), Madrid, Editorial Castalia1, 1971, p. 19.

Era esto echar las campanas a vuelo. Sorprende en la parte publicada, que es tal vez cuanto se conserva del epistolario de Cerdá, el silencio que había de guardar más adelante en cuanto al Parnaso. Terminada ya la publicación, sólo había de hacer alusión una vez, en carta a Mayans de 10 de agosto 1779, a un trabajo erudito propio en que se evitaría «la confusión» (es suya la palabra) que reina en la noticias biográficas del Parnaso, ya dado entonces por acabado.

Es de creer que con los descuidos (tan patentes en cada fe de erratas) y la desconcertante falta de método de Sedano, se enfriaron las relaciones entre los dos colectores. La virtud de filólogo de Cerdá, en nuestra opinión, no podía avenirse con tamaño desbarajuste. 
los cuales permiten entender lo que hacía más que sugerir su predecesor en la bibliografía de Sancha: «es imposible, aunque se componga a plana y renglón, lograr una igualdad absoluta en la distribución de las letras y los blancos, en el uso de letras defectuosas o de otras suertes, en las erratas, etc., además del reflejo de los usos habituales de cada componedor ${ }^{13}{ }^{\prime}$. Los tres volúmenes que imprimió Ibarra y se apropió Sancha años después para publicarlos sin más cambios que el de los pies de imprenta y el año eran, según la terminología hoy consagrada, «emisiones», no reediciones. Lo extraño es que nadie se dió cuenta de la sustitución operada por el impresor librero antes de que la señalara Rodríguez-Mońino, es decir que durante unos dos siglos quedó inadvertida.

¿Quién sabe, pues, si además de los tomos III, IV y V, no se adueñó Sancha del I y el II, que eran ya los únicos que le faltaban para disponer de otras colecciones completas? Sea lo que sea, tienen evidentemente mucho que ver esos detalles con el éxito comercial que habría de conocer nuestro Parnaso.

\section{ELEMENTOS DE CRÍtICA}

Los textos de presentación del Parnaso español: un prólogo en cada uno de sus nueve volúmenes, son todos de la misma pluma, incluso los que pueden leerse en los primeros volúmenes de la obra en que se dice que colaboró Francisco Cerdá. Parece que, de hecho, se limitó el erudito valenciano a buscar y reunir no pocas piezas (no todas, por cierto) sin que corrieran de su mano la selección definitiva ni la ordenación de los poemas. De modo que su participación en la empresa parece haberse limitado a suministrar material, siendo al fin menos trascendente de lo que pueden sugerirlo las dos cartas suyas, no muy explícitas, primero publicadas por Ángel González Palencia en un opúsculo que afortunadamente reproduce Antonio Rodríguez - Moñino ${ }^{14}$.

Sabido es que Cerdá, discípulo de Mayans según su propio decir, asumió y cuidó personalmente de numerosas reimpresiones de obras antiguas en castellano y en latín. Fue indudablemente el más destacado editor de su tiempo en lo que concierne a los autores "clásicos», correspondiendo perfectamente a la definición que del editor da la R. A. E.: «Persona que cuida de la preparación de un texto ajeno siguiendo criterios filológicos». Se

13. Jaime Moll, «Problemas bibliográficos del libro del Siglo de Oro», Boletín de la Real Academia Española, tomo lix -cuaderno CCXV, I enero- abril de 1979, p. 58 (49-107).

14. Antonio Rodríguez Mońino, op. cit., ibid. 
ha dicho a menudo que las contribuciones de Cerdá a la obra no pasaron del quinto volumen, alegación no documentada, que sepamos.

Pero lo que importa conocer de una obra que se ofrece al público no son tan sólo sus cualidades intrínsecas; sino sus diversas acogidas, su éxito comercial, su estimación, el placer con que se manejó. Si se toma en cuenta la recepción de la obra, no cabe duda que el Parnaso español interesó a eruditos y a estudiantes, a poetas con larga dedicación y a versificadores principiantes. A pesar de tantos desperfectos, consta que Cerdá al principio se dejó alucinar por esa publicación y que el tan exigente Mayans la vino adquiriendo, a no ser que se la hubiesen obsequiado.

La tuvieron en manos, tomo tras tomo, y durante más de medio siglo, no sólo sabios y eruditos sino también verdaderos poetas como Cadalso, Moratín el padre y otros literatos del primer Parnaso neoclásico.

\section{Prólogo y PROGRAMA}

Volviendo ahora al elemento que nos parece constitutivo de los «trozos selectos de literatura", veamos ahora qué fragmentos de crítica traen aparejados algún o algunos textos en que se explicita el propósito del colector López de Sedano. Este, desde luego, cumple ejemplarmente con el requisito de poner su obra en perspectiva en cada prólogo (hay uno por volumen), en las Noticias de los Poetas Castellanos que componen el Parnaso español, de carácter bio-bibliográfico y también en los Índices de las poesías que componen este Tomo ..., lejanos antepasados del comentario de texto. La parte crítica es pues abundante, y no cabe duda que contribuyó poderosamente al éxito de la colección, al tiempo que presentaba el flanco a numerosas y acerbas críticas.

Hay pues que admitir, por improbable que sea la cosa, que todos los prólogos son del mismo colector. Nos inducen además a pensarlo el talante y el estilo inconfundibles del editor

Desde las primeras líneas sienta éste un postulado que es el de la superioridad de los espańoles sobre cuantas naciones han existido y existen en el dominio de la poesía:

Entre las obras, que desean los hombres de gusto, y amantes de las glorias de la Nación, no era la menos principal una Selecta Colección de Poesías, con la qual se pudiese formar un Parnaso Español, no tan solo capaz de exceder a los modernos de las Naciones vivas, sino de competir con los antiguos de Grecia, y Roma (I, 1). 
Este pensamiento patriótico y el determinante «de buen gusto» bastarían para poder fechar esta declaración inicial del segundo siglo XVIII con toda seguridad.

Luego afirma Sedano que, si bien son notorias las muchas bellezas contenidas en las obras de los «clásicos poetas» españoles,

\begin{abstract}
no es menos profundo, y rico el tesoro que yace confundido, e ignorado, tanto en los mismos Poetas conocidos, como en otros muchos, que no han llegado a noticia aun de los aficionados a esta casta de erudición; ya por lo raras, que han hecho el tiempo, y nuestra desidia las Obras de nuestros más célebres Autores en todas clases; ya, lo que es más cierto, por el poco aprecio con que generalmente se mira la erudición Nacional; de que resulta la ignorancia de muchos ilustres Escritores Españoles y la indiscreta inclinación a los Estranjeros (ibid.)».
\end{abstract}

Aunque la palabra «afrancesado» queda en suspenso, no hay quien no capte esta alusión.

Ejemplo de obra maestra totalmente desconocida, prosigue el colector, es la égloga de Ardelia, que es «la mejor cosa que en su línea tenemos en Castellano, y que se encuentra en lo más acendrado de los Griegos, y Latinos». Puede el lector, al descubrir la tan elogiada composición entre dos poemas de Quevedo y Garcilaso, opinar que las hipérboles de Sedano se deben más al contento del descubridor que a la penetración de un crítico imparcial.

Valorando con nuevos argumentos la novedad de su colección, enumera el prologuista las colecciones afines que con varia fortuna se formaron con el fin de imprimirse:

Los Cancioneros antiguos son, a la verdad, unos tesoros preciosísimos, a los quales debemos la noticia, y la conservación de las Obras de muchos Poetas de los primeros siglos, de que sin su auxilio careceríamos irremediablemente. A éstos se agregan los Romanceros: colecciones también muy apreciables en su especie, que con este, u otros diversos títulos han recogido, y publicado sus Autores, de que tenemos abundante número, y a cuya clase se debe agregar el Tesoro de la divina Poesía por Esteban de Villalobos, impreso en Toledo en 1587. Pero de los tiempos posteriores, en que se incluye el siglo de oro de nuestra Poesía, no tenemos Colección alguna que merezca este nombre.

Pedro Espinosa, natural de Antequera, y uno de los buenos Poetas de su tiempo, fue el único que empezó a promover este designio, entresacando con delicado gusto algunas Piezas exquisitas de los Poetas más clásicos ya conocidos, y otras inéditas, y entre ellas 
algunas suyas, y formando de todas su libro, que intituló: Primera parte de las flores de Poetas ilustres Castellanos, impreso en Valladolid en 1605 (I, 2-3).

Luego, sin transición, la emprende Sedano contra ciertos «versificadores» de su tiempo, a los que deja en el anonimato, y recalca lo necesitados que están los jóvenes de tener un «modelo para fixar el buen gusto de la Nación».

Es muy posible que apunte el autor sucesivamente a los escritores afrancesados por una parte y por otra a los que caen en un insufrible prosaísmo.

Pasa luego a especificar los géneros poéticos que habrá de abarcar la colección: «todas las especies, y calidades de Poesías de moderada extensión», lo cual parece significar que no se atenderá únicamente a la lírica sino al conjunto de la producción en verso, incluso, señala el colector, «las mejores Versiones de las más célebres Obras de la antigüedad Sagrada, y Profana». Aquí se interrumpe el hilo del discurso relativo a las especies poéticas y promete Sedano, siempre confuso y atropellado,

muchas Poesías inéditas de ingenios de gran mérito; y otras, que aunque han sido impresas, lo raras, y desconocidas las puede hacer pasar por originales.

Después de este aviso, vuelve a su propósito anterior advirtiendo que los poemas épicos, aunque sobrepasan por su extensión lo que puede acoger el Parnaso español, estarán representados por unos trozos selectos.

Queda por delimitar la época en que florecieron los poetas cuyas composiciones se han de recoger. No puede tratarse de «los primeros siglos» con los casi mil trescientos poetas de los que alguna noticia recogió Nicolás Antonio desde Berceo. Algunos, a mediados de la centuria, empezaron a roturar aquel inmenso campo. Pero como se proponen los colectores de este Parnaso ofrecer modelos, ¿qué mejor elección que la poesía del Siglo de Oro?

esto es, desde los principios del XVI, en que Boscán y Garcilaso introduxeron en ella el buen gusto, sacándola de su antigua rudeza, hasta mediado el siglo XVII, sin que por esto se desechen algunas Piezas excelentes de Poetas anteriores a Garcilaso como asimismo de algún otro desde mediado del siglo pasado, época infeliz de la decadencia de nuestra Poesía, y nuestra Literatura, hasta el presente, como principio del restablecimiento de una y otra... $(1,6)$

Por si fuera poco, añade el autor a sus muchas promesas que para mayor realce de su colección se compromete a dar los retratos de los poetas en ella 
admitidos, feliz ocurrencia que no poco contribuyó al éxito de la obra a pesar de aumentar su precio.

Acaba el prólogo con unos tópicos sobre la trascendencia que siempre ha tenido la poesía, dando entrada al buen gusto en todas las naciones y todos los siglos.

Póngase atención en los límites cronológicos que se han asignado al Siglo de Oro y al «buen gusto» en este primer Parnaso español, que a despecho de lo que han afirmado ciertos estudiosos, no se elabora tan sólo para contrastar una época gloriosa y una ominosa decadencia, esquema dualista que durante tanto tiempo ha conllevado la noción de Siglo de oro. La construcción que aquí se nos ofrece evacúa el pesimismo de marras y enaltece a la nueva dinastía, la cual estaría dotada de la voluntad y el poder de restaurar cuanto se había abandonado y perdido bajo los Austrias. Este esquema tripartito: florecimiento -decadencia- restauración, que ya se han apropiado los ilustrados, es totalmente satisfactorio para la nueva monarquía, desde luego, y le permite apoyar una empresa como la del Parnaso español y otras muchas, realizándose así el ineludible proceso de apropiación cultural que se esperaba de los Borbones de España.

Que Luzán, Jorge Pitillas o el conde de Torrepalma estén representados en el Parnaso en compañía de tantos poetas del Siglo de Oro no debe pues chocar ni sorprender a nadie. Si en algo peca el propósito del colector, no es por cierto en esa elección, ya justificada y legitimada desde el mismo prólogo. Es el Parnaso español un monumento a la poesía del Siglo de Oro, fundamentalmente, pero no de modo exclusivo.

En la introducción al segundo tomo se reafirma por lo demás este designio. Muy ufano del éxito obtenido por la obra, se compromete Sedano a no omitir fatiga ni diligencia para dar más utilidad a su colección, insertando sin dilación en cada volumen lo que pensaba reservar para su final: unas Noticias históricas de nuestros Poetas, aunque no se le escapa que será imposible conseguir noticias de tantos autores.

Como ya se echa de ver, el Parnaso español fue una obra desde su principio en espectacular expansión. Se enriqueció y adornó para corresponder a una aceptación con que nadie había contado. Si todavía en vísperas de darse a luz se había anunciado como una humilde impresión en cuadernos sueltos, el impresor o, si no fue Sancha, quien sufragaba los gastos de impresión, había decidido por su cuenta y riesgo dar muchísima más envergadura, a una colección que no poco prometía pero que sólo había alcanzado en 1768 su primer volumen.

Por lo visto, el encarecimiento de los costes no amilanó a nadie, puesto que venía en el segundo volumen lo prometido en el primero: esos codiciados 
retratos grabados de los poetas famosos, que el público iba a quitarse de las manos. Por fin, y puesto a prodigar atenciones, ofrece ahora Sedano a los lectores otro adorno, que había reservado a los curiosos. Se trata de los Elogios poéticos de cada Autor al fin de su Noticia. Entiéndase que entregará el colector buena parte de los Viajes al Parnaso y otras fantasías afines que dejaron Lope de Vega, Cervantes, Zapata y Gil Polo, material que utilizará a menudo el colector, aunque no tanto como la colección de Pedro Espinosa.

Generalmente es insustancial, cuando no inexistente, el espíritu de examen y análisis en los prólogos del Parnaso español, cuyo propósito, ante todo informativo y comercial, no pretende sino dar contento a unos lectores cuyos deseos y cuyas expectativas habrán contribuido a moldear la obra.

Queda a pesar de todo otra categoría de textos en que debería manifestarse la estimación bien ponderada de todos los poetas. Son las noticias biográficas y en menor medida los índices de las piezas presentadas, en que no escasean los juicios de valor.

\section{Moradores de un Parnaso}

Aunque jamás alcanzó la obra aquellos doce volúmenes que en su inicio se prometían, no fue poco lo que al final del tomo noveno se había ofrecido al público. Nunca, por cierto, había visto la luz una colección de poetas tan rica, y además proveída, como era conveniente, de abundantes noticias, índices, e incluso, cosa que fue sumamente apreciada, de cuantos retratos habían logrado reunir la diligencia y el esmero, equiparando al escritor con el héroe y los demás grandes de este mundo.

Desearía el estudioso, hojeando esos millares de páginas, evaluar las predilecciones y el gusto que dejó traslucir Sedano en su labor. Para semejante asunto suele ofrecerse el método cuantitativo, que parece conllevar toda la exactitud de las matemáticas. Pero no hace falta pensarlo mucho para echar de ver cuántas dificultades surgen al querer determinar la base más pertinente de cálculo. ¿Serán el número y extensión de los poemas? Llegaríamos así a igualar un cuarteto y el texto íntegro de una tragedia (que las hay), un soneto y una égloga. ¿Iremos reduciendo hasta el verso y, ¿por qué no?, hasta cada uno de sus componentes, lo que convenga contar y recontar? 


\section{Autores de los cuales hay composiciones en el Parnaso español}

AcuÑa, Hernando de, II, 21 ; VII, 76.

AlcázAr, Baltasar del, IV, 112, 370 ; VII, 31, 88, 333 ; VIII, 264 ; IX, 124.

Argote de Molina, Gonzalo, IV, 55 ; IX, 1.

Arguijo, Juan de, IX, 140.

Barahona de Soto, Luis, II, 307 : VII, 93 ; IX, 53.

Bermúdez, Jerónimo Fr. (a nombre de Antonio de Silva), VI, 1 VII, 149 (inédito).

Borja, Francisco de, Príncipe de Esquilache, IV, 113 ; VIII, 225 ; IX, 195

Boscán, Juan, VIII, 373

Burguillos, Tomé de, I, 361; II, 207 ; IV, 99 ;VIII, 150. Sabe Sedano que Burguillos es seudónimo de Lope.

Calatayud, Francisco de, IX, 29.

Campo, Silvestre del, Pedro,VII, 347.

Carlos II, VII, 346.

Carranza, N, IX, 189.

Castilla, Francisco de, VII, 58.

Cayrasco de Figueroa, Bartolomé, III, 357 ; V, 332 ; VIII, 191.

Cervantes, Miguel de, VIII, 287 ; IX, 193.

CÉspedes, Pablo de, IV, 272.

Cetina, Gutierre de, VII, 75, 370 ; VIII, 96, 216 ; IX, 134.

Cueba, Juan de la, IV, 349 ; VIII, 1 ; IX, 259.

DueÑas (Licenciado), III, 362.

Ercilla y Zúñiga, Alonso de, II, 175.

Espinosa, Pedro, I, 343 ; V, 198, 371 ; VII, 166.

Ezquerra, Alonso, I, 330.

Figueroa, Francisco de, IV, 76.

Frias, Damasio de, II, 346,VII, 53, 165.

Gambaso, Dionis, IV, 144 (Sátira inédita).

Garcilaso de la Vega, I, 78 ; II,1.

Gómez Tejada de los Reyes, Cosme, IV, 100.

GÓMEZ DE TAPIA, III, 246.

GóngORA, Luis de, IV, 253 ; VII, 171 ; IX, 368.

HernándeZ de Velasco, Gregorio, I, 174, 187 ; V, 68.

Herrera, Fernando de, VII, 1.

Herrera, Juan Antonio de Lic ${ }^{\circ}$, IX, 154.

Hurtado de Mendoza, Diego, VIII 97.

JÁuREGUi, Juan de, I, 234 ; IV, 214 ; IX, 30

Lainez, Pedro, VIII, 402.

Ledesma, Alonso de, V, 183.

León, Fr. Luis de, I, 83, 180, 192, 204, ; IV, 266 ; V, 1 : IX, 183.

Leonardo de Argensola, Bartolomé, I, 226, 333 : III, 222 ; V, 54.

Leonardo de Argensola, Lupercio, I, 144, 157 ; III, 268 ; IV, 324 ; VI, 312. 
López de Zarate, Francisco,VIII, 173.

LuZÁN, Ignacio de, II, 137 ; IV, 157 ; V, 316.

Martín, Luis, I, 147 ; IV, 323.

Martín o Martínez de la Plaza, VIII, 394.

Medina Medinilla, Pedro de, VII, 133 ; IX, 354.

Medinilla, Baltasar Elisio de, IX, 354.

MesA, Cristóbal de, I, 198, 216, 221.

Montemayor, Geoge de, IX, 340.

Morales, Juan de, I, 71.

Morillo, Gregorio, I, 91.

Ortiz, Melgarejo, Antonio, VII, 132.

Pacheco, Francisco, III, 117 ; VII, 92.

Padilla, Pedro de, IV, 230.

Pantaleón de Ribera, Anastasio, VII, 312.

Paravicino, Hortensio Félix, fray, V, 319.

Pellicer de Velasco, Manuel, III, 104, 104.

Perea, Andrés de, II, 201.

Pérez de Oliva, Fernán, VI, 191 y 251.

Pitillas, Jorge, II, 318.

Polo, Gaspar Gil, I, 336 ; IV, 172, VIII, 265.

Polo de Medina, Salvador Jacinto, III, 338.

Quevedo, Francisco de, I, 65, 160 ; II, 329 ; III, 118 ; IV, 186 ; V, 287 ; VII, 221, 302 ;

VIII, 151 ; IX, 192, 371.

Rebolledo, Bernardino de, V, 199, IX, 155.

Rey de Artieda, Andrés, I, 352 ; IX, 194.

Rioja, Francisco de, IV, 49 : VIII, 217 ; IX, 19.

SaA de Miranda, Francisco de, VIII, 82.

Salas Barbadillo, Alonso Gerósimo de, VIII, 334 ; IX, 139.

SÁnchez, Miguel, V, 282.

Soto de Rojas, Pedro, IV, 296.

SuÁrez de Figueroa, Cristóbal, I, 167 ; III, 325.

Tejada, Agustín de, I, 168 ; V, 364, VII, 215

Torre, Francisco de la, I, 145, 327 : II, 128 ; III, 210 ; IV, 207 ; VIII, 163.

Ulloa y Pereyra, Luis, I, 123 ; VII, 334

VAldÉS Y MeléndeZ ; Lic ${ }^{\circ}$ Juan e, IX 351

VegA, Lope de, I, 100, 323 ; III, 1 ; IV, 23 ; VII, 99, 220 : VIII, 121 ; IX, 360.

Verdugo de Castilla, Alonso, Conde de Torrepalma ; III, 86.

Villarroel, Cristóbal de, V, 318.

Villegas, Esteban Manuel de, I, 30, 148 ; II, 67 ; III, 105 ; IV, 347 ; VII, 32 ; VIII, 367 ; IX, 3 .

ZAPATA, Luis, VIII, 329. 
En definitiva parece que lo más conducente es realizar un censo de los autores representados por alguna composición en la parte antológica de ese Parnaso. Luego bastará resaltar sencillamente las entradas que ostente el índice así formado, adoptando y adaptando la solución que dio don Antonio Rodríguez-Moñino a un problema análogo ${ }^{15}$.

Son 79 en total los autores que, con su nombre o algún seudónimo, figuran muy desigualmente en nuestra antología. Además, cosa algo impropia de un Parnaso, nueve poemas son "de autores inciertos», hallándose diseminadas esas anónimas piezas desde el tercer volumen por todo el cuerpo de la obra.

Del oscuro poeta sin identidad al más glorioso y laureado, allí están los que se consideran como el honor de la poesía espańola. Los eligió un editor o colector que no se guió únicamente por sus propias luces, pero que acabó con sus prólogos, noticias e índices (personales o no), por apropiarse la obra entera

¿Cuáles son en el Parnaso los ingenios de más mérito y fama? De utilizar tan sólo nuestro índice onomástico y sus referencias se conseguirían unas respuestas no del todo exactas pero sí aceptables mediante algún correctivo. Pero sucede que el propio Sedano nos suministra al respecto una opinión totalmente asumida y que debió de ser ampliamente compartida por una elite contemporánea. Dicha apreciación es tanto más de notar cuanto que topamos con ella en el último volumen de la obra y está respaldada por tanto por una labor de años. Se halla ésta en la Noticia de los poetas castellanos ... que concierne al Príncipe de Esquilache, evocando una estimación general y evidente:

... no faltan algunos que haciendo equívoco el dictado le gradúen por el Príncipe de los Poetas Líricos Castellanos; y aunque nosotros, con el común sentir de los Eruditos, no adheriríamos a esta absoluta calificación sin agravio de GARCILASO DE LA VEGA, DON ESTEBAN DE VILLEGAS, DON FRANCISCO DE QUEVEDO, el CONDE DON BERNARDINO DE REBOLLEDO, LUPERCIO Y BARTOLOMÉ LEONARDO DE ARGENSOLA, FRAY LUIS DE LEÓN, y LOPE DE VEGA, pondremos en el lugar que corresponde a nuestro PRÍNCIPE DE ESQUILACHE para que sobre estos ocho complete el número de los NUEVE famosos Poetas Castellanos que componen el primer orden de primera clase del PARNASO ESPAÑOL (IX, 35).

15. Cada una de las noticias dedicadas al Parnaso español por don Antonio va acompañada de una nómina de los "Autores de los cuales hay composiciones en este volumen", donde lo que se tiene en cuenta no es el número muy variable de piezas sino el nombre de los poetas, que se suceden y repiten sin orden alguno en cada tomo. Cada nombre da lugar a una entrada única. 
Sorprende que Fernando de Herrera parezca relegado a un segundo lugar, cosa que el instrumento imperfecto que es el índice no permite asegurar. La noticia que se le dedica en el tomo 7 contiene por cierto grandísimos elogios pero también unas censuras dignas de nota que deben citarse:

Pero causa admiración el ver que en medio de que nuestro Autor poseyó el talento y la ciencia necesarios para formar un verdadero Poeta, no se manifiesta siempre en sus Composiciones aquella perfección que indispensablemente debía producir esta unión admirable; y es la causa que queriendo esmerarse con exceso en limar y pulir su estilo y sus versos, los dejó demasiado duros, secos y faltos de aquel jugo y suavidad que es el alma de la cadencia y harmonía poética a que se agrega la afectación que usó de muchos términos y frases antiquadas, con los apóstrofes y otras figuras, y signos que tomó de la Poesía Toscana... (VII, 9-10).

Es evidente que la comprensión de Herrera se le hacía muy cuesta arriba a don Juan José.

Ahora bien, el autor más vapuleado es, claro está, Góngora, del que se dice que, muy estimable en muchas de sus producciones, se convirtió después en un extraño e inquietante maniático, habiendo ya desde niño dado muestras de la patología mental que le aquejaría más tarde.

Pasemos ahora piadosamente a lo que es la grandísima novedad de este Parnaso. Se trata a todas luces de la radiante omnipresencia de Esteban Manuel de Villegas, con júbilo festejado por los ilustrados, los cuales, de pronto lo convirtieron en clásico eterno, no menos por esa «independencia y travesura juvenil» que habría de señalar Quintana, que por sus dotes de helenista y su invención de una nueva poesía ligera ${ }^{16}$. Este poeta, y el ya celebrado Príncipe de Esquilache, aunque sobretodo el primero, constituyen los dos más espectaculares rescates llevados a cabo en la formación del Parnaso español de las Luces.

Tras la primera constelación presentada, se da también indudable relieve a los autores siguientes: Góngora (a pesar de todo), Gutierre de Cetina, el tan socorrido Espinosa, Jáuregui, Cristóbal de Mesa, Gil Polo, Rioja, Barahona de Soto, Espinel, Agustín de Tejada y otros cuyo nombre aparece un par de veces en nuestro índice.

A pesar de sus limitaciones, permite ver esta nómina dos cosas que entre otras merecen reparo. La primera es que el número de poetas de más excelsa

16. Manuel José Quintana, Tesoro del Parnaso español, o Poesías selectas castellanas, Paris, Baudry, 1838, Introducción, p. 18. 
fama, que serán de ocho o nueve en concepto del mismo colector y en comparación de los 79 comprendidos en la selección, infunde la sospecha de que menos que la excelencia, que no siempre sabía apreciar, lo que le importó a Sedano fue impresionar y maravillar por la copia y profusión.

Claro que el conocimiento que podía tener cualquier lector de la poesía áurea, su principio y el comienzo de su «restauración", dista mucho de lo que hoy se sabe y debemos precavernos de graves anacronismos siempre que de estimaciones y gustos lejanos se trate. Procurando soslayar este riesgo hemos consultado para un rápido cotejo con el Tesoro del Parnaso español de Quintana en su magnífica edición definitiva de 1838 (Paris, New-York). Hubiera sido tal vez preferible utilizar la primera, de 1807, pero aparte de que estuvo ésta desacreditada por el propio autor, nos podía valer indiferentemente cualquier edición correcta para cumplir con nuestro propósito. Quintana, como se sabe, empezó a adquirir cierta notoriedad hacia 1787, casi al mismo tiempo que sus mayores de la generación de 1780, a quienes le unían afinidades esenciales. Al final de dicha obra, que viene a rematar una labor de unos treinta años, se halla un índice de los «Autores comprendidos en esta colección» que, salvando unas significativas diferencias de organización respecto de las colecciones anteriores, fácilmente nos pone a la vista aquellos poetas que, habiendo florecido del siglo XVI a los primeros decenios del XVIII, es decir dentro de los límites temporales definidos por Sedano, se prestan a una pertinente comparación entre ambos parnasos.

Pues bien, son 35 los elegidos por Quintana en su madurez. Y puede verse que todos han logrado y conservado cierto renombre cuando no una indiscutida fama dentro y fuera de España. No puede decirse otro tanto de los 79 autores convocados por Sedano en su muy promiscuo Parnaso. Si frecuentemente, huelga decirlo, han escogido los dos colectores a los mismos poetas, es más lo que los diferencia que lo que los acerca, lo cual es cuestión de erudición y gusto, no de oposición generacional.

Cotejando los índices onomásticos de nuestras dos antologías advertimos que no son numerosos, aunque sí importantes a veces, los autores selectos de Quintana que faltan en la obra de Sedano. Se trata de Mira de Amescua, Balbuena, Juan de la Cruz, Francisco Manuel, Diego Mejía y Diego de Mendoza. En cambio abundan los escritores que pretendió salvar el Parnaso de Sedano con desigual y a menudo ingrata fortuna. Claro que los hay muy famosos, los cuales son dignos de recordación como humanistas y polígrafos más que como poetas, verbigracia Argote de Molina; pero lo más notable y grave es que mucho se propasó Sedano en su presunta elección que ni reúne lo mejor ni desecha el ripio o el relleno, sacando de un caritativo olvido cantidad de versificadores de nulo interés. Si las antologías posteriores, la de 
Quintana por ejemplo, pudieron compartir con el Parnaso español un elenco (todavía incompleto) de poetas castellanos del Siglo de oro (y sus décadas colindantes), llegando a amasar un tesoro de unos 35 autores, se excede la de su precursor en formar una junta de 79 individuos, dos veces y algo más cuantiosa de lo que exigía el simple discernimiento. Así lograron llegar a nuestros días poetas de tan modesto vuelo como Francisco de Calayud, Silvestre del Campo, Carranza N., Francisco de Castilla, Bartolomé Cayrasco de Figueroa, Alonso Ezquerra, Dionis Gambaso, Gómez de Tapia y otros muchos cuyas composiciones recogidas como al azar, por no decir a ciegas, van de lo mediano a lo indigente ${ }^{17}$. Esa fue, a pesar de todo, la fuente en que beberían los ilustrados algo adictos a la poesía, y se verá que sus maestros les enseñarán a separar el grano de la paja.

\section{Primeros poetas de LA ILUSTRACión}

Si fue Ignacio de Luzán precursor de la nueva poesía en España, nos parece que fue modesta su aportación a la lírica.

Quien iba a ejercer a partir de los años 1770 una influencia personal decisiva, aunque sin tener una obra abundante, fue José de Cadalso, contertulio en la fonda de San Sebastián de Nicolás Fernández de Moratín, quien regentaba a la sazón la cátedra de Poética de los Estudios de San Isidro. Era dicha fonda, como bien se sabe, el sitio donde más se hablaba de poesía, de traducciones y colecciones de textos. También cabe decir que fue la verdadera cuna hispano-italiana del neoclasicismo, gracias a los trabajos del conde Juan Bautista Conti y a su inteligencia crítica de comparatista.

La correspondencia de Cadalso con don Nicolás y, por otra parte, la estrecha relación que se estableció en 1773-1774 entre el oficial y los poetas, muy jóvenes o ya algo experimentados de la llamada «escuela de Salamanca», nos ofrece la oportunidad, tal vez única, de saber sobre qué peculiares problemas de fondo-forma reflexionaron en alguna ocasión nuestros neoclásicos. Hay por ejemplo una carta de Cadalso a Moratín en que demuestra el primero ser más versado en prosodia latina que su corresponsal, recalcando la total imposibilidad de adaptar al castellano «la práctica colocación de las breves y

17. Decía don Marcelino para templar la severidad de sus críticas: «La empresa era grande y de difícil o más bien imposible realización en el estado que entonces alcanzaban los conocimientos bibliográficos, pero sólo el haberla acometido y continuado por bastante espacio, desenterrando alguna vez verdaderas joyas, como la canción A Itálica, la Epistola moral etc., hará siempre honroso el recuerdo de Sedano». Marcelino Menéndez Pelayo, Historia de las ideas estéticas en España, Madrid, MCMLXII, 1961, III, p. 308. 
largas» ${ }^{18}$. Acercar los dos idiomas hasta fundirlos fue algo con que soñaron como otros tantos esos apasionados de la Antigüedad romana. De la poesía griega tomaban los temas bucólicos, como habían hecho los latinos, pero bien se dieron cuenta los más perspicaces de que el alto y oscuro lenguage de Píndaro mal podía entenderse y menos aún imitarse sin muchísima prudencia. Lo que escribe al respecto Cadalso es de gran interés por señalar los límites que habían de tener en aquelle época la imitación y la elección de ciertos modelos antiguos. Véase cuánto sugieren estas pocas líneas:

Mil veces me he lastimado a solas del mal ejemplo que nos ha dado a los poetas posteriores la elevación de Píndaro, y de que una tan buena causa produjese efectos tan diferentes.

Horacio fue el primero que conoció la hermosura de aquellos versos sublimes, y también la dificultad de imitarlos. Su oda que empieza: Pindarum quisquis studet aemulari demuestra una y otra verdad; bien que haya en ella más bellezas y menos defectos que en todas las composiciones posteriores llamadas con más o menos razón pindáricas. Hernando Herrera fue el primer español que se puso despacio y exprofeso a imitarlo en la canción sobre la batalla de Lepanto y en la pérdida de Don Sebastián en Africa. León y Lope tienen algunos rasgos de este género, pero no iguales al dicho aunque tal vez superiores a él en otros... No sé si Góngora y sus desatinados secuaces creyeron imitarlo, en cuyo caso sería menester huir de tal camino por no dar en iguales precipicios ${ }^{19}$.

Esto no es nada menos que uno de los mejores testimonios de la época sobre el arduo problema que podía a veces plantear la imitación por un lector moderno de la Antigüedad griega y romana. Y era perfectamente ilustrativa al respecto la oda II (libro IV) de Horacio, ya que revelaba la inmensa admiración de aquel poeta, a buen seguro el clásico de los clásicos, por el difícil y oscuro lenguaje de Píndaro. ¿Cómo podía ser que los modernos no tuviesen la capacidad de entender lo que para su tan cercano y querido Horacio era sin velo accesible? Había cierta zona opaca entre la cultura latina y la griega que resistía al saber de las Luces, y habían de pasar casi dos siglos para que se cayera en la cuenta de que no había sido clásica toda la Antigüedad.

Pero, sin tratar de extender tanto la vista, senálaba Cadalso en su carta la impronta más o menos visible que habían dejado en la poesía hispana la

18. José de Cadalso, Escritos autobiográficos y epistolario, Prólogo, edición y notas de Nigel Glendinning y Nicole Harrison, London, Tamesis books limited, 1979, p. 80 y 84.

19. Op. cit., p. 98. 
imitación de Píndaro, la inclinación al estilo elevado y sublime de Herrera, a veces de Lope y quien sabe si no también de Góngora y sus secuaces.

La estancia de Cadalso en Salamanca y luego las cartas que escribiera a los que habían sido a la vez sus amigos y sus discípulos: Meléndez Valdés, José Iglesias de la Casa, Juan Pablo Forner, León de Arroyal, contribuyeron decisivamente, como se sabe, a arraigar vocaciones y a orientar a unos jóvenes manteístas hacia los estudios humanísticos y los autores castellanos del Siglo de Oro. Es muy apreciable lo que se sabe de los poetas predilectos de Cadalso, del que nos han quedado bastantes cartas y escritos íntimos donde es frecuente que hable de la poesía por de dentro ${ }^{20}$.

Entre los clásicos latinos, son los más mencionados o citados Virgilio, Horacio, Ovidio, y tal era la familiaridad del oficial con los dos últimos que ambos a la vez dejaron su huella en ciertos poemas. En cuanto a Píndaro, como hemos visto, es para él el genio que sólo otros genios pueden atreverse a imitar.

Los autores castellanos son numerosos y se nota que han guiado su elección unos claros criterios. Todos han florecido en el siglo XVI y las primeras décadas del XVII: Garcilaso y fray Luis de León, por supuesto, Hurtado de Mendoza, Francisco de la Torre, Herrera, Lope, Quevedo, Luis de Granada y el tantas veces nombrado e imitado Villegas.

Desde luego otras referencias pueden suministrar las obras escritas de cara al público, como Las Cartas marruecas, pero preferimos utilizar la fuente que permite saber en qué asuntos poéticos se ocupaba Cadalso con sus amigos de Salamanca. La carta relativa a Píndaro y sus posibles imitadores es de 25 de marzo y va dirigida "a uno de los amigos de Salamanca», que pudo ser el malogrado Arroyal. Es muy probable que haya sido leída en voz alta por todo el grupo de estudiantes ya nombrados. Mientras perduró la «Academia cadálsica» y hasta la muerte de Cadalso en 1782 fue frecuente que recibieran los aprendices de poetas muchos consejos de lectura relativos tanto a la literatura latina como a la española. No cabe duda que el Parnaso español de López de Sedano, cuyo último tomo se publicó en 1778 fue lectura predilecta de Cadalso y su tertuliantes y que siempre se desveló éste para que no faltara ni un volumen a su colección de poetas castellanos ${ }^{21}$. También consta que Meléndez tenía la misma obra en su biblioteca y no es aventurado afirmar que iba ésta pasando de mano en mano casi cada noche en la tertulia salmantina.

\section{Ibid.}

21. Cadalso menciona frecuentemente el Parnaso de Sedano cuyos volúmenes le iban llegando a donde quiera que estuviese. 
Como no abunda la documentación utilizada, que se reduce a algunas cartas del oficial, no deben formularse sin prudencia las conclusiones generales que sobre la historia de la poesía española estaría uno tentado de formular. Procuremos al menos, y utilizando varias fuentes, esbozar para cada uno de los jóvenes del grupo salmantino, pertenecientes a la generación de 1780 , una relación de sus poetas más admirados. Debemos a G. Demerson una lista de obras que había leído Meléndez Valdés entre 1777 y $1780^{22}$. La poesía española del Siglo de Oro está en ella representada por los Argensola, Boscán, Camoens, Ercilla, Esquilache, Garcilaso, Góngora (unos romances), Fray Luis de León, Montemayor, Polo, Quevedo (el Epicteto), Lope de Vega y el omnipresente Villegas. Añádase el Parnaso español, que pudo haber sido un buen estímulo para adquirir parte de lo anterior.

Otros manteístas que concurren a la academia cadálsica en los mismos años que Meléndez son Arroyal y Forner. El primero, poco recordado como poeta, es gran admirador de Villegas, Luis de León, Garcilaso y Herrera. De este último, tan compartido por Cadalso y sus discípulos, no existe ninguna reedición en el siglo XVIII ; sólo es posible leerlo en edición antigua o en las composiciones sueltas del Parnaso español y de algún periódico posterior.

En cuanto a Forner, que será un buen poeta según los cánones de su época, hará desfilar por las páginas de sus Exequias de la Lengua castellana, que es a la vez una chirriante sátira menipea y un Viaje al Parnaso con todas las de la ley, la siguiente cohorte: los Argensola, Arguijo, Rey de Artieda, Balbuena, Boscán, Cueva, Ercilla, Espinel, Espinosa, Esquilache, Figueroa, Garcilaso, Herrera, Hurtado de Mendoza, Jáuregui, León, Montemayor, Pérez de Guzmán, Pérez de Oliva, Rebolledo, Rioja, Rufo, Santillana, Soto de Rojas, Tanco de Fregenal, Tejeda Páez, Teresa de Jesús, Torre, Torres Naharro, Vélez de Guevara, Villamediana, Villegas, Virués, Zárate ${ }^{23}$. Eso sin olvidar a lo poetas dramáticos que no merecen menos honores: Lope y Calderón, Mira de Amescua, Guillén de Castro, Vélez de Guevara, Montalván, Rojas, Moreto, Hoz, Zamora ${ }^{24}$.

Recuérdese que los escritores en ciernes que rápidamente hemos evocado eran realmente muy jóvenes y que cuando tuvo Cadalso que separarse de ellos definitivamente tenía Meléndez 20 ańos, Forner 18, Arroyal 19. A

22. Georges Demerson, Don Juan Meléndez Valdés et son temps, Paris, Librairie C. Klincsieck, 1962, p. 53-56.

23. Juan Pablo Forner, Exequias de la lengua castellana. Da una lista de los autores mencionados Marta Cristina Carbonell en su edición muy cuidada de Madrid, Cátedra, 2003, p. 367-395.

24. Op. cit., ed. cit. 
pesar de lo cual confiaba el oficial en su talento y hasta pensó en recoger sus producciones y las propias en "un Parnaso español de poetas hoy vivos ${ }^{25}$ ».

Pocos años después, hacia 1780, se disgregaría, aunque sin desunirse, el grupo, permaneciendo Meléndez, Iglesias y fray Diego en Salamanca, mientras que de los demás dos se irían a Madrid a buscar destino.

\section{UNA COLECCIÓN DE POETAS ESPAÑOLES}

Después de las muertes tempranas de Nicolás Fernández de Moratín en 1780 y Cadalso en 1782, quienes tuvieron que asumir en cierta manera el relevo en la carrera de las letras españolas, fueron principalmente Meléndez, Moratín el Joven y Forner, que en los primeros años de 1780 -un poco antes en el caso de Meléndez-, empezaron a publicar y a lograr cierto renombre, siendo galardonados los tres aún novicios en los concursos de la Real Academia Española.

Conocen los dieciochistas la existencia de una tertulia literaria de Madrid, llamada por algunos la tertulia del convento de la Victoria, que vino a sumarse en los años 1780 a la de la Fonda de San Sebastián, más cosmopolita y distinguida. En aquel lugar, y más precisamente, en la celda del escolapio Pedro Estala, profesor de Humanidades en el Colegio San Fernando, se reunían unos jóvenes, clérigos y seglares, ora para chacotear, ora para hablar con apasionamiento de bellas letras. Disponemos al respecto de un testimonio directo, aunque bastante alejado de la época de los hechos referidos, que debemos a un gran amigo de Moratín el hijo:

Cuando yo comencé a tratarle (a don Leandro), en el año de 1781 si mal no me acuerdo, había muerto su padre, y vivía en la calle de las Hileras (...) Desde entonces concurríamos los dos casi diariamente a la celda del padre Estala hasta cierta hora de la noche, que cerraba el convento, y los domingos, si el tiempo era bueno, en la Aganipe, nombre que le había dado Leandro a una fuente del Retiro ${ }^{26}$.

Entre los tertuliantes estaba Forner que había dejado para siempre a Salamanca y a Meléndez, a quien había de tener admiración y afecto durante toda su vida. A la sazón (1782-1783) ya había trabado con Moratín y con Estala una entrañable amistad. Esos tres autores, hay que decirlo, eran los que daban mayor realce al grupo. Allí, entre burlonas diversiones y

25. Cadalso, op. cit., p. 113

26. Juan Antonio Melón, «Desordenadas y mal digeridas apuntaciones», B.N.E. ms. 18.666. 
ambiciosos ensueños nació la idea de acometer una gran empresa editorial, susceptible no sólo de competir con el Parnaso español, cuyo volumen IX y último, salido en 1778, seguía despachándose y siendo una novedad, sino de superarlo y con mucho por una más exigente elección de autores y, desde luego, instaurando el orden, método y erudición que se echaban de menos en la obra de Sedano.

¿Quién concibió este proyecto? Se opina hoy día, y con autoridad, que fue Estala el que hizo concepto de la cosa, la fue llevando solo durante años y acabó por confiarla a un continuador que aceptó hacerla llegar a buen puerto. Todo esto está bien documentado y puede aceptarse en bloque. Pero es más que verosímil que el erudito huésped que, durante ańos y casi a diario, estuvo acogiendo en su tertulia un nutrido grupo en el que destacaban dos bien preparados poetas, haya a veces consultado con ellos cuanto se refería a la elaboración del nuevo Parnaso.

Debió de debatirse, entre otras muchas cosas, el nombre y título que había de darse a la obra: ¿Parnaso? ¿Colección? ¿Biblioteca? Se optó finalmente por el más neutral de "Colección», que no tenía el encanto de «Parnaso», pero sí la ventaja de no prometer tanto y ser el más adecuado. Asimismo se tomó la decisión de señalar algo como una relación entre la futura obra y un desconocido personaje, lo cual, lejos de aclarar lo que fuese, había de suscitar no poca perplejidad entre los estudiosos durante más de dos siglos. Nos referimos al quidam designado en el título: Ramón Fernández. ¿Quién sería ese individuo cuyos nombre y apellido tan castizos más de una vez habían servido de seudónimos?

Hoy día, gracias a René Andioc, sabemos a ciencia cierta que Ramón Fernández no fue un seudónimo, como se conjeturó hasta nuestros días, ni el nombre del barbero de Pedro Estala, como también se supuso, sino un cirujano que durante años estuvo sufragando la impresión de la obra y publicando traducciones por su cuenta ${ }^{27}$.

Según eso, el reparto de los papeles debió de ser el siguiente:

$1^{\circ}$ Editor, en la más antigua acepción de la palabra, Pedro Estala. $2^{\circ}$ Colaboradores ocasionales en la concepción de la obra, elección y recolección de los textos: varios contertulios. Sólo está documentada la participación directa de Forner, pero nos parece muy plausible la de Moratín, que no se interesaba solamente por la historia de la escena sino también por la de la lírica, como había de mostrarlo muchos años más tarde

27. La portada dice así: Colección de poetas castellanos, publicada por Ramón Fernández. Madrid, Imprenta Real, 1786 (1798). Son 20 vols. Sobre el editor: René Andioc, «Ramón Fernández siempre será Ramón Fernández», Madrid, Insula, 1988, 504, p. 18-19. 
componiendo sin tener a mano su biblioteca una rica antología del soneto desde su introducción en Espańa.

$3^{\circ}$ Algunos personajes influyentes, como Eugenio de Llaguno, que era oficial de la Secretaría de Estado y desempeñaba otros importantes cargos, proporcionaron en ciertas ocasiones libros y códices o facilitaron el acceso a tal cual biblioteca. Eso está documentado.

$4^{\circ}$ Proveedor de fondos (o editor, en la entonces muy reciente acepción del término): Ramón Fernández.

La impresión la realizaría la Imprenta Real, bien equipada y en pleno auge.

\section{Peripecias de UNA PUBliCACIÓN}

$\mathrm{Al}$ emprender la edición del primer volumen parece haber Estala vacilado entre dos resoluciones: la de presentar cada volumen como una impresión suelta y autónoma o bien como un tomo destinado a ser incluido en una colección. La presencia o ausencia de un número de tomo en la portada y el lomo bastaba, en principio, para diferenciar las dos opciones. Pareció prevalecer la primera cuando vieron la luz las Poesías de Francisco de Figueroa, llamado el Divino, dadas a luz por Estala en 1785, sin prólogo ni numeración. Dicho volumen, durante no pocos años, no se integró a la colección, ni se menciona en el "prólogo crítico» de la obra, carencia por la que pedirá disculpas el colector al tener que enfrentarse con unos detractores de su Figueroa. Pero desde el año siguiente, en 1786, empezaron a salir con prólogo e indicación de tomo unas rimas de los Argensola, en 3 volúmenes, de Herrera en dos, de Jáuregui en uno. Numerados de 1 à 6, constituyeron una primera entrega, copiosa y prometedora. Ya sí que formaban parte esos volúmenes de la Colección de Ramón Fernández.

En adelante proseguiría la publicación con esa alternancia de interrupciones y simultáneas ediciones de varios tomos. Debe el estudio de la obra tener en cuenta y destacar esas etapas, lo cual puede hacerse mediante esta disposición:

\section{Año 1786}

Rimas del secretario Lupercio Leonardo de Argensola. I

Rimas del doctor Bartolomé Leonardo de Argensola. II

Rimas de Bartolomé Leonardo de Argensola. III

Rimas de Fernando de Herrera. IV $y \mathrm{~V}$

Rimas de Don Juan de Jáuregui. VI 
Año 1789

Farsalia de Don Juan de Jáuregui. VII

Farsalia de Don Juan de Jáuregui. VIII

Poesías de Don Luis de Góngora y Argote. IX

Año de 1790 (puede tratarse de la misma remesa)

Poesías del maestro fray Luis de León. X

Año de 1792

Rimas Humanas y Divinas del licenciado Tomé de Burguillos. XI

Obras de Christóbal de Castillejo, secretario del emperador don Fernando. XII

Obras de Christóbal de Castillejo, secretario del emperador don Fernando. XIII

Año de 1795

Conquista de la Bética: poema heroyco de Juan de la Cueva. XIV

Conquista de la Bética Bética: poema heroyco de Juan de la Cueva. XV

Poesías escogidas de nuestros cancioneros y romanceros antiguos. XVI.

Año de 1796

Poesías escogidas de nuestos cancioneros y romanceros antiguos. XVII.

Año 1797

Poesías inéditas de Francisco de Rioja y otros poetas andaluces (Fernando de Herrera

- Juan de Arguijo - Baltasar del Alcázar - Diego Mexía). XVIII.

Las Heroydas de Ovidio traducidas en verso castellano por Diego Mexía. XIX.

Poesías de Francisco de Figueroa, llamado el Divino. XX.

El primer interrogante que suscita este cuadro concierne a las interrupciones que pone a la vista. Podrían sencillamente deberse a que Estala, después de entregar los seis primeros volúmenes al impresor, necesitara tiempo para ir preparando los siguientes. Pero aparte de que parecería excesivo el tiempo requerido por dicha labor, nos induce más bien a pensar esa táctica de ejecución y pausa, no exclusiva de la primera sugerida, en una financiación que se hubiese escalonado cada dos o tres años después de una importante inversión inicial. Nótese cómo fueron ordenados los autores de la Colección en la primera serie (I a VI) que aparece en 1786 y no tiene continuación hasta 1789, cosa de la que no pudo Estala ser tenido por responsable, ya que tenía dispuestos los tomos VII y VIII en 
1789, y poco después los IX a XIII, que saldrán a luz en 1790. Todo esto queda claramente demostrado por María Elena Arenas Cruz que se apoya principalmente en documentos de censura, y advierte además que se daba por entonces cierta tirantez entre el editor y su proveedor de fondos Ramón Fernández, motivo por el cual había corregido el primero en malas condiciones las pruebas del Góngora ${ }^{28}$.

Se da una nueva interrupción hasta el año 1792, en que se publican el tomo X, consagrado a fray Luis de León, y el XI a las Rimas de Tomé de Burguillos (no considerado por Estala como un heterónimo de Lope de Vega), y las obras de Cristóbal de Castillejo (tomos XII-XIII).

Como bien lo nota María Helena Arenas Cruz, no se hallan en estos últimos volúmenes los habituales prólogos y advertencias, sino, como más, algún texto breve que en ningún caso los puede sustituir.

Un documento que hace años encontramos en el Archivo Histórico Nacional aclara lo que le está aconteciendo durante aquel año al socio de Estala, Ramón Fernández. Es algo banal y sencillo, pero totalmente inesperado en vista de sus considerandos.

En él se expone que después de sufragar los gastos de impresión de los quince primeros volúmenes el solicitante, se da cuenta de que en ningún momento ha podido resarcirse con las ventas y decide renunciar a tan ruinoso negocio ("hallándose el suplicante por ahora imposibilitado para poder seguir dicha colección»), cediendo todos sus derechos a la Imprenta Real que se quedará con las numerosas existencias de la colección desde hace años acumuladas.

Se le concede a Ramón Fernández lo que desea y se procede a un minucioso ajuste de cuentas para liquidación del asunto. Esto sucede entre diciembre de 1792 y fines de febrero del $1793^{29}$.

Mientras tanto se está imprimiendo, según declara entonces Ramón Fernández, la Conquista de la Bética de Cristóbal de Castillejo. Esos dos volúmenes, XIV y XV, no se pondrán a la venta antes de 1795, y en provecho de la sola Imprenta Real, sin que figure en la portada el nombre de Ramón Fernández. Lo cual es lógico. No lo es tanto, en cambio, que los tomos siguientes vean la luz rezando en su portada que son Continuación de la colección de Ramón Fernández, lo cual no era estafa, pero sí mentira a medias,

28. Sobre nuestro autor, somos deudores de casi toda nuestra documentación a la obra todavía reciente de María Elena Arenas Cruz, Pedro Estala, vida y obra. Una aportación a la teoría literara del siglo XVIII español, Madrid, CSIC, 2003. Sobre la corrección del Góngora, véanse las p. 167-168.

29. Madrid, A.H.N. Consejos, 11.280/44. 
aunque siempre se podrá alegar que «Ramón Fernández» se había convertido en marca registrada.

¿Quién eligió y preparó el texto de Castillejo? Estala, a juicio de María Elena Arenas. Es en efecto lo más probable.

No sabremos, a no ser que aparezca una nueva documentación, lo que fue en adelante de Ramón Fernández ni de sus relaciones y tratos con Estala. Lo único cierto y ya bien conocido es que a partir del tomo XIV y hasta el último (el XX) tomó a su cargo las ediciones un hombre muy representativo de la generación que inmediatamente seguía a la de los años 80 , el joven y ya muy erudito Manuel José Quintana. Él fue quien corrigió las pruebas de los dos tomos de la Conquista de la Bética (XIV y XV) por más que le pesara, ya que le merecía muy poco aprecio su autor. Pero lo que más contento debió de darle fue ser el único responsable de los dos volúmenes de poesía de los Cancioneros y Romanceros (a los que antepuso una nutrida y muy notable presentación). Así se verificaba lo que había desechado explícitamente Sedano : dar entrada a esa poesía "de todos», tan a menudo menospreciada, introduciendo en suma varias antologías en otra antología.

El tomo XVIII: Poesías inéditas de Francisco de Rioja, y otros poetas andaluces, contiene de hecho composiciones de Hernando de Herrera, Juan de Arguijo, Baltasar del Alcázar. Los acompaña una breve pero sustancial introducción.

El tomo XIX: Las Heroydas de Ovidio traducidas en verso castellano por Diego Mexía no llevan prólogo ni notas, por tanto cualquier corrector se hubiera bastado para evacuar este cometido mínimo. Parece sin embargo que se sacrificó Quintana una vez más. Años más tarde haría José Marchena este comentario festivo sobre esta última elección:

¿Qué es ver en la colección de poetas de don Ramón Fernández, junto con los Argensolas, Herrera, Rioja, y el Maestro León, un Diego Mejía, colocado entre nuestros poetas clásicos, sin duda como Saúl entre los Profetas? ${ }^{30}$.

Tal vez no fuese al respecto muy distinto el juicio de Quintana. Pero con eso y todo él sustituyó a Estala a partir del volumen XIV, siguiéndole los pasos en tan dificultoso ejercicio como es hacer compartir por muchos sus gustos y predilecciones. Apuntemos que el volumen de las Poesías de Francisco de Figueroa, llamado el Divino, mal acogido cuando salió en 1785,

30. José Marchena, Lecciones de Filosofía moral y Elocuencia, o Colección de los trozos más selectos de Poesía, Elocuencia, Historia, Religión y Filosofía moral y política de los mejores autores castellanos, Ed. de Fernando Díaz Plaja, Madrid, Alianza editorial, «El Libro de Bolsillo», 1985, p. 187. 
vino a constituir el tomo XX y último de la colección, aparentemente porque así lo habían concertado Estala y Quintana. Estaba impreso desde 1785, por tanto parece tratarse quizás de una nueva emisión.

\section{PoEsíA Y CRÍTICA}

En los textos de presentación de la Colección, en particular en el «Prólogo del editor» que viene encabezando todo el conjunto, es donde se halla lo nuevo y sustancial. La postura adoptada en ese prólogo, hace de la obra un verdadero manifiesto literario y nacional, que consiste en afirmar la especificidad del lenguaje poético y la radical diferencia que se da entre éste y el de la prosa. Tras una primera y vigorosa exposición en el texto que precede a las rimas de los Argensola, vuelve a la carga Estala en el prólogo que escribe a las rimas de Fernando de Herrera, lugar en verdad ideal para exponer las convicciones que le mueven. En la argumentación que se halla en esas casi ochenta páginas utiliza el autor sus sólidos conocimientos de helenista para esbozar una brillante historia de la poesía desde Homero, oponiéndose enérgicamente a cuanto se escribe en Francia sobre la confrontación de la prosa y el verso. Aunque no lo explicita, estamos convencidos de que la opinión combatida con ardor es la del filósofo d'Alembert o sea el famoso teorema de d'Alembert, muy coreado en Francia, hasta el punto de considerarse como una expresión del genio francés. Enunciado en 1760 expresa lo siguiente :

\footnotetext{
Voici, ce me semble, la loi rigoureuse, mais juste, que notre siècle impose aux poètes: il ne reconnaît plus pour bon en vers que ce qu'il trouverait excellent en prose $^{31}$.
}

Según Estala, pues, el genio francés y el español no pueden ser más distantes ni distintos; nunca sabrán los poetas galos lo que es verdaderamente la poesía. Lo supieron los españoles cuando su lírica rivalizaba con la griega, sin tener más rival que la italiana.

Este combate por la poesía no carece de precedentes. Un viejo conocido nuestro, Juan Pablo Forner, había sostenido pocos años antes en una cruenta polémica con Iriarte exactamente la misma tesis con notable vigor ${ }^{32}$. O sea

31. Hace tiempo que hemos abordado en una perspectiva española este tema muy trillado en Francia. V. François Lopez, Juan Pablo Forner y la crisis de la conciencia española, trad. de Fernando Villaverde, Junta de Castilla y León, Consejería de Educación y Cultura, 1999 (1a ed. 1976), p. 291 y s.

32. Véanse Juan Pablo Forner, Cotejo de las églogas, ed. cit., y sobre todo el trabajo de Pedro Ruiz Pérez, a quien mucho debe esta ponencia, incluso su inspiración: "Vuelos y raptos 
que Forner y Estala sobre este tema candente defendieron la misma causa. Les permitía su conocimiento de las culturas antiguas saber que en sus orígenes la poesía, por su inspiración no menos que por su lenguaje, estaba estrechamente unida aún a lo sagrado, que así la hicieron vivir sacerdotes y fieles. De allí que en el remoto nacimiento de la poesía griega Píndaro y Homero adoptaran

Aquel lenguaje enteramente poético, ageno de toda semejanza con la prosa, y propio de las deidades. Los demás Poetas griegos, líricos, trágicos, bucólicos adoptaron un lenguaje propio de cada uno de estos géneros de poesía; pero todos en sumo grado poéticos, y muy agenos de la prosa (7-8).

Buen helenista y traductor de Sófocles, ve muy bien Estala que las polémicas sobre el teatro y las reglas que deben regirlo dimanan del desconocimiento o el rechazo de los textos griegos fundamentales. Esa carencia llevó a los franceses a disputar sin fin de la estructura de la tragedia, descuidando lo que tocaba al lenguaje y era precisamente lo esencial. Aunque no la explicita este agudo crítico, implica su argumentación una idea muy nueva, casi revolucionaria, que formularemos con conceptos actuales, y es que no iban tan descaminados los españoles del siglo XVII al dar en sus obras la primacia al colorido, a la tonalidad, al estilo en suma, sobre cualqiuer precepto puramente estructural.

Todo esto que es muy novedoso en los años 1780-90, lo remata nuestro crítico con estas citas de Herrera y Aristóteles que hacen irrefragable su alegato en favor de un lenguaje poético que será nuevo de puro antiguo :

Nuestra lengua, hija en la mayor parte de la latina, aumentada y adornada de infinitas voces y frases griegas, hebreas, arábigas, admite sin dificultad todas las bellezas propias de todas estas lenguas...

Véase lo que el mismo Herrera dice en orden a las voces extrańas : «Lícito es a los escritores de una lengua valerse de las voces de otra; concédeseles usar las forasteras y admitir las que no se han escrito antes; y las nuevas, y las nuevamente fingidas, $y$ las figuras del decir, pasándolas de una lengua en otra. Y quiere Aristóteles que se admitan en la poesía voces extrangeras y que se mezcle de lenguas para dar gracia a lo compuesto y hacerlo más agradable y más apartado del hablar común. Porque, como él dice en el libro tercero de la Retórica, las dicciones extrañas hacen que la oración parezca más grande ...»

poéticos", Estala, Herrera y lo sublime», Bulletin Hispanique, n 1 - Juin 2002, Hommage à François Lopez, Bordeaux, Université Michel de Montaigne, p. 391-423. 
Incitan irresistiblemente estas razones a examinar con atención lo que el mismo Estala había de opinar en el tomo IX de su Colección de las obras de Góngora. Se sabe que para publicarlas tuvo nuestro crítico que doblegarse ante las intimaciones de un censor real para quien era peligroso que viera la luz cualquier producción de un autor en cuyos escritos iban juntos lo mejor y lo nefando ${ }^{33}$. El texto que escribió entonces Estala nos parece ser de una inteligencia y una mesura sin equivalente en la crítica ilustrada. Hay más: si no aprueba nuestro autor las libertades que se tomó Góngora en sus grandes poemas, no cabe duda que para él el cordobés y Herrera el sevillano fueron los dos grandes inventores de lenguajes poéticos que había tenido la poesía española.

Reproducimos esas curiosas páginas en apéndice para que puedan nuestros lectores apreciar la audacia, la insolencia tal vez, que espejea en esas páginas de todos modos ambiguas, que por este motivo bien merecen una lectura plural y contrastada, contradictoria si cabe.

\section{DE FLOR, PARNASO Y TESORO A ANTOLOGÍA}

El documento por el cual se declaraba insolvente Ramón Fernández y, más aún, la cuenta de todos los ejemplares sin vender a la que se procedió, nos llevan a pensar que para todos los volúmenes, hubo mala venta y perjuicio comercial. Ahora bien, si no hay duda de que así fue, también nos parece innegable que mejoró el negocio al quedar totalmente en manos de la Imprenta Real. Hablan los hechos: entre 1792 y 1825 salieron varias ediciones de las que renunció a dar cuenta Palau, cuyas noticias al respecto son muy decepcionantes. Actualmente no los posee en su totalidad la Biblioteca Nacional. Parece que la Colección, cuyo éxito no había sido suficiente entre 1786 y 1797, necesitó un largo espacio de tiempo para cumplir con el cometido de toda obra: ser comprada y leída. Y mientras se difundía lentamente, en medio de invasiones y luchas armadas, salía a competir con ella la primera antología de Quintana, las Poesías selectas castellanas desde el tiempo de Juan de Mena (Madrid, 1807, con sus varias reediciones) y la tan subversiva de José Marchena (Burdeos, Beaumé, 1823), quedando finalmente las dos desbancadas por el Tesoro del Parnaso español en su edición definitiva. (1835-38). La Colección, no tan malograda como podía pensarse, llegó a ser obra de fondo en las librerías de España, y es

33. Las insistentes recomendaciones del censor Ignacio López de Ayala en María Elena Arenas Cruz, op. cit. 
muy posible que tuviera mejor despacho a la altura de los ańos 1825 que al iniciar su andadura. Le hacían por entonces compañía en el comercio de lance el Parnaso de Sedano y la tercera edición del Tesoro del Parnaso español de Quintana, antología cabal, modélica, que lograba compaginar una buena elección de autores y una crítica erudita a la par que elegante. Ya estaba fijado un género editorial, literaria y materialmente; ya había empezado el primer gran siglo de las antologías, si bien se mira inaugurado por la generación de 1780 . 
Poesías de D. Luis de Góngora y Argote. Por D. Ramón Fernández. Tomo IX. Madrid, en la Imprenta Nacional, 1820

82-3-11

Formato reducido

\section{(p. 5)PROLOGO}

Ofrecemos al público el tomo ix de nuestra Colección de Poetas, que comprende las poesías escogidas de D. Luis de Góngora y Argote, presbítero, y capellan de honor del Rey, y racionero de la santa iglesia de Córdoba, de donde era natural. Asi que, nos es indispensable dar razon á los amantes de la poesía española, particularmente á los jóvenes, en cuya gracia nos hemos tomados este trabajo, porque de todas las obras de este autor sea tan corto el número á que nos hemos ceñido, omitiendo el Polifemo, el Panegírico al Duque de Lerma y sus célebres Soledades. A la verdad, si á medida que nuestra nacion puede presentar un número muy considerable de poetas, cuyas obras son y han sido inagotables manantiales para los extrangeros, hubiéramos tenido la felicidad de que estos grandes ingenios hubiesen tenido aquel juicio que requiere Horacio, y que admi-

(p. 6) ramos en las obras de los antiguos, no necesitaríamos en el dia apología mas convincente de la superioridad y ventaja que les haríamos en este ramo de bella literatura, que con tanto ardor y felicidad cultivamos en los siglos XVI y XVII. Pero ha sido tal nuestra desgracia en esta parte, que aquellos varones á quienes la naturaleza parecia haber dotado con mas liberal mano de talento poético, han carecido ó no han hecho caso de aquel fino y delicado juicio, que es la luz y guia del ingenio, y sin el que las composiciones que se aplauden por mas acabadas y perfectas no serian mas que versos falsos de sustancia y sonoras bagatelas. Y aunque esto se verifique en algunos poetas del siglo XVII, parece que en ninguno se demuestra con mas evidencia que en las composiciones que omitimos del presente autor, que publicamos. Este sublime ingenio, adornado sin duda de la erudicion y talento necesarios á un poeta, no queriendo contenerse en los límites que prescriben la naturaleza y arreglado juicio, se dejó arrebatar inconsideradamente de su fan-

(p. 7)tasía desordenada, y llevado del deseo de la gloria, emprendió abrir sendas no trilladas hasta entonces de ninguno, constituyéndose por cabeza de la secta dicha vulgarmente del Culteranismo ó de los Cultos, extraviando consigoá otros muchos, que si hubieran dado oidos á su razon, vivirian hoy por sus trabajos literarios en nuestra memoria. Como el deseo de exceder y sobresalir entre los que son de una misma profesion sea natural, y tanga tanto poder en almas ahidalgadas y espíritus generosos; no contento con los aplausos que se merecia por su dulzura lírica, sales festivas y sátiras picantes 
y graciosas, se abandonó al volcán de su imaginacion y al desarreglado entusiasmo de su fantasía, desviándose del camino que siguieron los anteriores á él Garcilaso, D. Diego Hurtado de Mendoza, y sus contemporáneos los dos Argensolas y D. Francisco de Quevedo. Asi que, el deseo sin duda de sobresalir y de hacerse admirar fue el objeto que se propuso en la composicion de las Soledades y Polifemo, los cuales poemas sufrieron la justa

(p. 8)censura de sus coetáneos, lo que no impidió que dejasen de seguir la novedad sugetos por otra parte muy sabios, tales como el Conde de Villamediana, Pedro Soto de Rojas y Fr. Felix Hortensio Paravicino. Siendo sus imitadores muy inferiores en talento y erudicion á su maestro, las producciones que se daban al público estaban llenas de hinchazon, faltas de claridad en el lenguage, de verdad y justicia en las ideas, y de todas las demas condiciones que se necesitan para que los trabajos de los sabios nos interesen, propagándose esta graciosa gerigonza de estilo casi hasta nuestros dias. Como en aquellos tiempos era costumbre de comentar los poetas de mayor nota, linage de trabajo muy propio para ostentar erudicion portentosa, y conseguir por este medio fama de eruditos, se aplicaron unos á ilustrar y comentar, y otros á defender el estilo figurado de su maestro, que á la verdad ninguno lo necesitaba mas, como fueron D. García de Salcedo, coronel, caballero del hábito de santiago, D. Francisco de Amaya, D. martin Angulo, D. Juan Andres

(p. 9)ustariz, Martin Vazquez Siruela y D. Josef pellicer. Nosotros no queremos entrar á departir con sugetos tan dignos de nuestro respeto, y nos abstenemos de bregas gramaticales; particularmente estando ya decidida la cuestion que dió motivo á tantas críticas, sátiras é invectivas á favor y en contra de las Soledades, Polofemo y Panegírico, que D. Nicolas Antonio dice ser comparable, y poder competir con los mas perfectos de los antiguos. A la verdad el tiempo, que es el juez mas íntegro y desapasionado, y el censor insensible de las obras de los sabios, ha calificado las Soledades y Polifemo como una produccion extravagante, en quien reinan la hinchazon, la oscuridad, la afectacion, y todos los desórdenes de una imaginacion caldeada excesivamente. Pues siendo la prueba incontrastable de la bondad de una obra su duracion, y el gusto con que leida una vez se vuelve á leer otra y otras muchas veces, tocamos por la experiencia el ningun caso que hacen en el dia los sensatos de las Soledades, habiéndose ya dado el título de gongorino á cualquier au-

(p. 10) tor que se eleva algun tanto sobre lo que requiere la materia que trata. Homero, Virgilio, Garcilaso y Cervantes serán eternos en la memoria de los hombres mientras durare el amor de la literatura. ¿Por qué? Por la acertada eleccion del asunto, por el orden que observan, y por el modo de 
ofrecer y presentar á la imaginacion sus pensamientos; condiciones que son el fundamento, forma y decoracion de cualquier obra; pues decidiendo del asunto la eleccion acertada de la materia que se ha de tratar, el orden establece el plan, y el modo arreglado de representar las ideas forma el estilo. Cuando este no es proporcionado al asunto, no llamara nuestra atencion sino por breves momentos: el asunto sin el estilo conveniente no nos agradará sino, digámoslo asi, á medias, y uno y otro sin el plan no merecerá nuestra aprobacion sino por muy corto tiempo. Mas cuando todas estas tres cosas estan reunidas y enlazadas entre sí mutuamente, entonces excitan en nosotros aquella impresión, entusiasmo y triunfo de la sensibilidad de nuestra alma, que

(p. 11) son la verdadera causa de que nos interese y agrade. Pero este agrado é interes no puede tener origen sino en la verdad, que en materia de poesía es la union de semejanzas, cuya realidad es tan consistente y sólida, que resiste á la necia estupidez de unos, á la soberbia delizadeza de otros, al despoptismo pasagero de los falsos censores, á los gritos de la envidia, al entusiasmo pedantesco, á la ignorancia, á la opinion, á la preocupacion, y últimamente se conforma y ajusta entreamente con los preceptos del arte. Si esta union y enlace del asunto con las sensaciones agradables que excitan en nosotros es solo aparente y ficticio; si depende de las circunstancias, de la imaginacion, de la preocupacion, prontamente empezarán á desagradar, y del desagrado pasará al menosprecio, y de este al olvido, por ser su interes y situaciones locales y ficticias. Esto mismo parece ha sucedido con las Soledades y con saci todas las composiciones heróicas de Góngora. Arrastrados de la novedad, muchos se encantaron con la aparente hermosura sin cuidar de la razon

(p. 12) ni de la verdad, y alucinados de la apariencia, y sojuzgados por el ejemplo, eligieron mas bien ser maestros de la mentira y pintores de quimeras, que discípulos de la realidad poética, esto es, de la bella naturaleza. Ciertamente que con bastante justicia y propiedad se pudieran comparar las Soledades á aquellas nubes, que miradas desde lejos, parecen una dilatada cordillera de montańas; pero tocadas de cerca, se ve que no son mas que vapores que se huyen al tacto. Si la claridad es una virtud del lenguage, la oscuridad, por mas elegante que sea, no dejará de ser vicio, y reprensible, requiriéndose tambien como virtudes necesarias al estilo la propiedad, la facilidad y armonía.

Prescindamos pues del plan y del orden, que son las condiciones que dijimos ser indispensables fundamentos de una obra, y digásenos cuál de estas virtudes se halla en las Soledades. Si se quiere hablar con ingenuidad, no hallamos sino ideas indigestas, imágenes extravagantes, locuciones 
tenebrosas, afectacion de voces latinizadas, metáforas violentas, ale-

(p. 13) gorías impropias y mal conducidas, traslaciones forzadas, y finalmente desorden, y tal confusion estrepitosa de palabras, que el que las lee una vez no puede menos de sentir haber gastado tan mal el tiempo, y compadecerse juntamente del autor que tenía fantasía tan desarreglada.

Sin embargo, la lengua adelantó mucho, y subió á cierto grado de perfeccion muy elevado, ya por los términos que dedujo de las lenguas latina y griega, ya también por la frase y torneo con que la enriqueció, en las cuales cosas si no hubiera sido tan atrevido, y hubieran sido mas moderadas y finas las inflexiones que hizo de estas lenguas, seria muy digno de imitarse en esta parte en toda su extension.

Mas las composiciones que presentamos, aunque no estan libres de algunos pequeños lunares, sin embargo distan mucho de las que omitimos, pues en los sonetos hallamos elevacion heróica en los pensamientos, orden y novedad, propiedad y elegancia en las voces, hermosura en las frases, y aquella vivez y rodeo armónico que hacen suave y enérgica la dic-

(p. 14) cion. Las letrillas y romances estan adornados de tal agudeza, chistes graciosos, sal satírica y dichos espirituosos y festivos, que si no se nos concede ser superior, al menos es preciso confesar que es comparable á los mejores de nuestra nacion, y que hace muy conocida ventaja á los mas excelentes de cualquier otra. Cuando habla, digámoslo asi, naturalmente, se deja ver la sublimidad de su genio poético, y aptitud para todo género de poesía, ya épica, ya lírica, y particularmente epigramataria; mas como de esta manera no haria muy conocida ventaja á los que le precedieron y á sus contemporáneos, era forzoso descubrir otro camino para la alabanza. Y en esto podemos conocer que regularmente queremos sobresalir, y hacernos admirar en ciencias y artes por aquel camino á que menos nos llama la naturaleza y conduce el genio, no logrando otra cosa regularmente que hacernos ridículos; siendo cierto que si nos dirigiéramos por donde ella nos lleva, y siguiésemos nuestra natural inclinacion, seríamos perfectísimos en la ciencia ó profesion á que nos aplicásemos.

(p. 15) Lo cual vemos claramente en Góngora, pues teniendo particular genio para lo satírico y chistoso, quiso oscurecer y aventajarse á todos por donde menos podia, ó le era mas violento. Esta pues ha sido la causa por que se ha hecho poco caso de su mérito, no leyéndose sus letrillas y romances burlescos, de los que en la mayor parte es inimitable. No se puede negar que era varon de grande ingenio, como le llama D. Nicolas Antonio, y que si hubiera sabido contenerse en aquellos límites que prescribe el juicio, hallándose dotado de grande erudicion e incomparable amenidad, hubiera sido la tortura de sus contemporáneos, y el mas envidiado de su siglo. 
Tocante á las memorias de su vida sabemos que fue natural de Córdoba, como ya se ha dicho, de una de las mas nobles familias de la ciudad, habiendo nacido á 11 de julio de 1561; que pasó á Salamanca de edad de quince años con objeto de estudiar ambos derechos; pero llevado del estudio de las bellas letras, se aplicó á la poesía y humanidades, siendo fru-

(p. 16) to de estos trabajos todas las poesías amatorias y burlescas. A los cuarenta y cinco años se ordenó de sacerdote, y obtuvo una racion de la santa iglesia de Córdoba. Pasó despues á Madrid, en donde, con la proteccion del Duque de Lerma y Marques de Siete Iglesias, consiguió la plaza de capellan de honor del Rey D. Felipe III, granjeándose la estimacion y obsequio de las personas mas distinguidas de la corte; pero habiendo enfermado de un raro accidente, nque le dejó privado de la memoria, se retiró á su patria, en donde murió en 1627, habiendo vivido sesenta y seis años. 